\title{
Classroom Climate, Academic Self-Concept, Learning Self-regulation, and Academic Identity Status among EFL Students: A Structural Equation Modeling Approach
}

\section{Saeedeh Mohammadi}

* Correspondence:

s.mohammadi.tefl@gmail.com

English Department of Farhangian

University, Shahid Beheshti Branch,

Zanjan, Iran

Received: 23 March 2020

Revision: 21 May 2020

Accepted: 6 July 2020

Published online: 20 September 2020

\begin{abstract}
Practical improvements in students' overall success can be made if we take into account the contribution of learning environments to learners' various attributes that would greatly affect their academic selves. This study aimed at scrutinizing the possible associations among Iranian EFL students' perceived classroom climate, academic self-concept, learning selfregulation, and academic identity status. 420 university students were asked to fill out College and University Classroom Environment Inventory (CUCEI), Academic Self-Concept (ASC) Scale, Learning Self-Regulation Questionnaire (SRQ-L), and Academic Identity Status (AIS) Questionnaire. Using Structural Equation Modeling (SEM) and based on its several goodness-of-fit criteria, the proposed model of the possible interactions of the main variables was confirmed. Furthermore, classroom climate was correlated positively with subscales of learning self-regulation and academic self-concept and negatively with academic identity status. Besides significant correlations among study variables, the final model also revealed some intra-scales associations. Multiple regression analysis also indicated some significant predictions. The findings could provide classroom instructors and university syllabus designers with implications so that they can plan the EFL environments and class activities taking into consideration students' various academic characteristics. This involves their status of selfconcept, identity, and regulation to help them achieve highly recognized long-term academic objectives.
\end{abstract}

Keywords: classroom climate, academic self-concept, learning selfregulation, academic identity status, structural equation modeling 


\section{Introduction}

The diverse features of an academic setting in which learning a foreign language occurs seem to have linkages with the learners' various academic characteristics; in other words, in an environment with few academic features, academic relations, and academic rules, difficulties will arise in the academic establishment of the personality and cognitive characteristics of the individuals in that setting. In university classroom climates in which the non-academic issues rather than academic ones influence the individuals' academic selves, the realization of the academic ends of that specific context is not much expected.

Wherever the climate characteristics and academic features of the individuals are ideally met, learners, whose selfconcept has been influenced by the classroom climate, would be able to self-regulate the speed and path of their learning. Besides, in case that the requirements have been all met, it is highly expected that the characteristics of the learning environment would influence the academic identity of the individual learners. Thus, it is conceived that the current research on the associations among classroom climate, academic self-concept, learning self-regulation, and academic identity status can elucidate their importance in the English as a Foreign Language (EFL) learners' academic outcomes. Self-concept has long been considered as one of the crucial academic attributes. Academic self-concept is a particular type of multifaceted self-concept developed through interactions with students and in relation to their academic roles. Also, it is a dynamic process as a student progresses through education (Rosen, Glennie, Dalton, Lennon, \& Bozick, 2010). Past research has significantly enhanced understanding of how students' critical appraisals of themselves play a role in how successful they can function as learners (Bong \& Clark, 1999).

Learning self-regulation is another academic attribute in the learners which involves their ability to control and manage cognition, interests, action, and environment to achieve academic objectives. Generally, two types of learning selfregulation can be identified. Autonomous regulation, on one side, comprises intrinsic motivation and identified or integrated forms of extrinsic motivation (Deci \& Ryan, 2000). Intrinsic motivation underlies behaviors engaged for learners' own pleasure, interest, and satisfaction (Levesque, Williams, Elliot, Pickering, Bodenhamer, \& Finley, 2007). An individual with identified regulation demonstrates more self-determination since he/she finds the desired behavior and regulation process as personally necessary (Sun \& Chen, 2010). Also, the most self-determined type of extrinsic motivation is integrated regulation which occurs "when a behavior is perceived as being part of the larger self, as being connected to other values and behaviors" (Levesque et al., 2007, p. 692). Controlled regulation, on the other side, consists of extrinsic regulation that focuses on receiving rewards, avoiding punishment, or satisfying others such as parents or teachers as well as interjected regulation which refers to behaviors which avoid damage to ego and is controlled by the person himself (ibid.).

In addition to academic self-concept and learning self-regulation, learners' academic identity status was adopted as another important academic property. It deals with first how students establish relationships with others in academic settings, second how they are understood by others, including teachers, family members and friends, and third learners' underlying motivations to attend university classes. These issues have impacts on second language acquisition (SLA) leaners' behaviors inside and outside of the class. According to Was and Isaacson (2008), academic identity is a specific part of "ego identity" and also a distinctive aspect of the identity development. Peirce (1995) argues that "SLA theory needs to develop a conception of the language learner as having a complex social identity that must be understood with reference to larger, and frequently inequitable social structures reproduced in day-to-day social interaction" (p. 13). In essence, language learning is part of one's identity and is used to convey this identity to others (Thanasoulas, 2002).

Marcia's theory, as a referenced theory of identity status, shows four identity states that an individual may find oneself in: foreclosed, diffuse, moratorium, and achieved. Following Was and Isaacson (2008), we describe academic foreclosure as the way EFL learners internalize academic values and goals that they have taken from others (most often parents). Academic diffusion is a lack of exploration and commitment leading to failure in deciding about academic issues. Academic moratorium is a time of academic indecision, uncertainty, and exploration to reach a conclusion about academic goals and values. Finally, academic achievement is the healthy conclusion to the academic identity crisis which signifies a commitment to a set of academic values formed after a period of exploration.

\subsection{Statement of the Problem}

Despite a great wealth of research on academic variables, the paucity of current research as well as the inconsistency in findings call for a closer examination of how classroom climate, academic self-concept, and learning self-regulation 
are inter-correlated and how they jointly affect academic identity status. Besides, considering the above-mentioned academic constructs, past research has paid little attention into the investigation of possible associations among these variables in such EFL contexts as Iran. Moreover, it is conceived that the potential interactions among the academic learner variables of classroom climate, academic self-concept, academic identity status, and learning self-regulation may determine the type, speed, and course of the individuals' learning process in university EFL classes more than other variables.

Since classroom environment has been found to play a major role in shaping the quality of educational life and amount of learning (Fraser, 1998; Peters, 2013), in order to ensure adequate performance, it is incumbent on us as teachers to recognize how learners' preferred and perceived classroom climate characteristics can associate with various learner attributes. Thus, the findings of this study have the potential to guide the EFL teachers, and language and syllabus programmers to understand the contribution of different classroom aspects to learners' capabilities. This study can also help them to identify how learners' perceived academic climate, their self-concept, ability to self-regulate learning, and their motivations to start and continue higher education are associated. Also, it helps the EFL teachers to recognize ways in which they can improve their students' academic self-concept, learning self-regulation, or academic identity status. Besides, how strongly one academic attribute is linked with another attribute can offer implications for academic practitioners and researchers. These implications highlight the need to conduct the present research. It is noteworthy here that, although these constructs are well known and have been discussed in many earlier studies, the study has the potential to make sound and unique contribution to the field through the investigation of the possible relationships using the Structural Equation Modeling (SEM). The SEM can reveal all the relations among several variables simultaneously, demonstrating the relative contribution of each variable to the variance in a result.

\subsection{Research Questions}

Accordingly, the current study aims to examine the inter-relationships between learners' perceived classroom climate, their academic self-concept, learning self-regulation, and academic identity status and the links among their underlying components. More specifically, present study aims at addressing the following research questions:

- What are the interactions among EFL students' perceived classroom environment, the students' academic selfconcept, learning self-regulation, and academic identity status?

- How are the errors of observed variables related to each other?

\subsection{Research Hypothesis}

In order to examine the first research question, the following null hypothesis was formulated:

H0: There are no interactions among EFL students' perceived classroom environment, their academic self-concept, learning self-regulation, and academic identity status.

\section{Review of Literature}

Research on the study of psychosocial dimensions of classroom climate has received increasing attention. Plethora of research has indicated significant correlations between subjectively perceived environments and such matters as learners' academic achievement, their amount of motivation and engagement, socio-cognitive outcomes, and many other variables (Aldridge \& Fraser, 2008; Anderson, 2001; Dorman, 2001; Dorman, Fisher, \& Waldrip, 2006; Ebrahimi, Eskandari, \& Rahimi, 2013; Frenzel, Pekrun, \& Goetz, 2007; Joe, Hiver, \& Al-hoorie, 2017; Mohammadi \& Aliakbari, 2018; Pawlowska, Westerman, Bergman, \& Huelsman, 2014; Peng, 2019; Peters, 2013). Dorman (2001), for instance, revealed associations between classroom environment and academic efficacy of the learners. Anderson (2001) also found that the environmental factors had a more powerful effect on motivated behavior than the personality measures.

Moreover, a substantial body of literature confirms strong correlations between academic self-concept and academic achievement (Awan, Noureen, \& Naz, 2011; Erten \& Burden, 2014; Jaiswal \& Choudhuri, 2017; Lambert, 2007; Matovu, 2012). Through mediation analyses, Areepattamannil (2011) also indicated a similar correlation through the mediational role of intrinsic and extrinsic motivation. Academic self-concept has been also found to serve as a significant and strong predictor of foreign language learning motivation (Liu, 2010). As regards the relations between learners' self-concept in general and academic self-concept in specific and their classroom environment, few studies have been reported. Persad (1980) found intricate ties between an organized, supportive, and innovative classroom 
environment, peer and family self-concept, and student satisfaction. Saki, Fallah, and Zareei Mahmoodabadi (2013) also revealed a significant relationship between mathematics classroom environment and Iranian learners' selfconcept. Similar results were also obtained by Singh and Sarkar (2015) in an Indian context. Generally, it is believed that students who perceive their needs for classroom involvement and affiliation to be fulfilled by their classroom environments tend to be environmentally encouraged toward developing positive academic self-concepts (Knight \& Waxman, 1990).

As regards the third variable in the study, considerable research has focused on investigation of the ways in which learning self-regulation is linked with individual academic outcomes (Herring, 2013; Wang, Liu, \& Chye, 2010). Generally, autonomous regulation has been found to lead to better performances than controlled regulation (Deci \& Ryan, 2000). Also, Ryan and Connell (1989) and Liu, Wang, Tan, Ee, and Koh (2009) indicated that while external and interjected regulations in school children were related to anxiety and maladaptive behavior, identified and intrinsic regulations were linked with enjoyment and effort. Autonomous or controlled regulation has been also identified to be affecting students' dropout in exams (Herring, 2013).

A number of studies in educational psychology have demonstrated some direct and indirect links between students' perceived classroom environment and their learning motivation and self-regulation (Alzubaidi, Aldridge, \& Khine, 2016; Dabbagh \& Kitsantas, 2011; Paris \& Paris, 2001; Ross, Salisbury-Glennon, Guarino, Reed, \& Marshall, 2003; Sungur \& Gungoren, 2009; Wijnia, Loyens, \& Derous, 2011). For instance, Ross et al. (2003) reported that contextual variables like teaching approach influenced students' self-regulation and achievement. Generally, classroom environments enhancing complex thinking skills and active student participation were more likely to promote selfregulation. Paris and Paris (2001) also identified a developed learning self-regulation in student-centered classroom environments where students have control over their learning and have the chance to cooperate more with their friends.

As regards the fourth variable in the study, the relations between academic identity status and other learner variables have been investigated in a number of past studies. Some studies confirmed interesting ties between academic identity and the types of study strategies (Was, Isaacson, \& Wessel, 2007), achievement goals adopted by university students (Was, Harthy, Stack-Oden, \& Isaacson, 2009), and personality and behavioral traits (Buch, 2007; Puspoky, 2018). Despite a paucity of research on the role of motivation (Phinney, Dennis, \& Osorio, 2006), Allan, Johnson, and Szostak (2009) supported a recursive model in which identity status significantly affected this motivation both directly and indirectly. Nonetheless, classroom climate appears to be intricately connected with academic self-concept and learning self-regulation, although how they separately and jointly influence academic identity status is unclear.

\section{Methodology}

\subsection{Design of the Study}

The study applied a quantitative design in which the participants were asked to provide their answers to four Likertscale self-report measures. More specifically, structural Equation Modeling (SEM) was adopted to investigate the potential interactions among classroom climate (CC hereafter), academic self-concept (ASC hereafter), and learning self-regulation (LSR hereafter). The SEM allows the investigation of both indirect and direct effects, and provides statistical indices for evaluating the global fit (De Marie, Miller, Ferron, \& Cunningham, 2004). Fig 1 shows the initial proposed model drawn using SEM to investigate the potential links among the study variables.

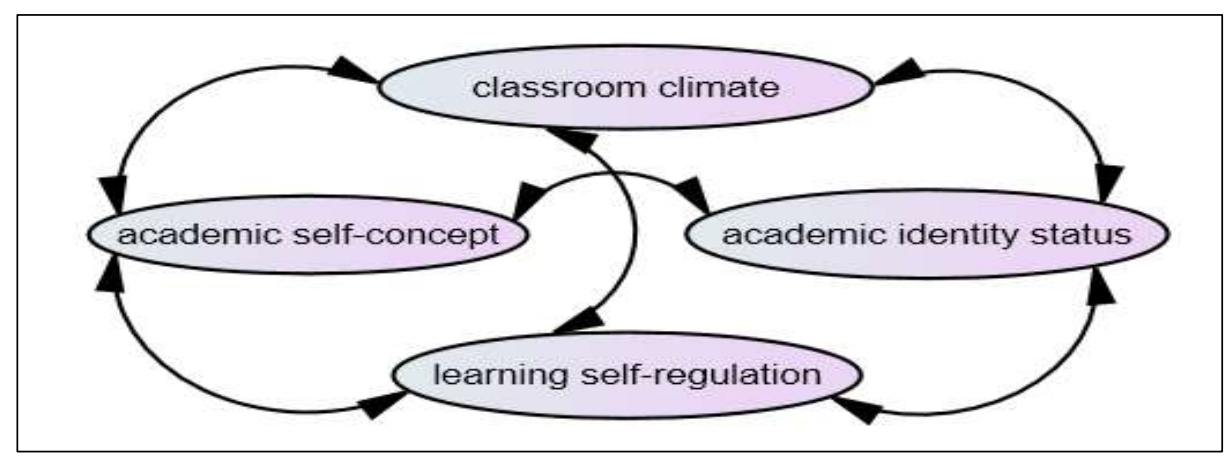

Figure 1. The initial proposed model of the relationships among the main variables of the study 


\subsection{Participants}

420 Iranian EFL university students in Ilam, Zanjan, and Guilan provincies participated in this study. They were of 18-23 years of age studying at the educational level of BA in the fields of Language Translation, Teaching, Literature, and Linguistics selected through cluster random sampling. Consent was also sought from all the participants to participate in the study.

\subsection{Instruments}

\subsubsection{Classroom Climate Questionnaire}

In the current study, CC is operationally defined as the way Iranian EFL learners perceive different psychosocial dimensions of their classroom environments. In this regard, College and University Classroom Environment Inventory (CUCEI) was used which has been developed and validated by Fraser, Treagust, and Dennis (1986). It is a 49 item questionnaire which encompasses seven subscales, seven items in each, involving personalization $(\alpha=.75)$, involvement $(\alpha=.70)$, student cohesiveness $(\alpha=.90)$, satisfaction $(\alpha=.88)$, task orientation $(\alpha=.75)$, innovation $(\alpha$ $=.81)$, and individualization $(\alpha=.78)$.

\subsubsection{Academic Self-Concept Questionnaire}

The construct of ASC involves a mixture of Iranian learners' self-evaluations regarding their general academic abilities and roles in academic settings. These self- appraisals concern EFL learners' degree of academic confidence and effort in university settings. The scale developed by Liu and Wang (2005) was used to measure students' Academic SelfConcept (ASC). It had two sub-scales; (a) Academic Confidence (AC), and (b) Academic Effort (AE), each with 10 items. The items included both negatively and positively worded items and they were not in order in the scale. The scale used in the study involved a 6 point Likert format, which ranged from 1 (strongly disagree) to 5 (strongly agree). The Cronbach alphas of the ASC scale, AC subscale, and AE subscale were .90, .83, and .84, respectively.

\subsubsection{Learning Self-Regulation Questionnaire}

LSR is defined as EFL learners' ability to control and manage their cognition, interests, action, and environment so as to achieve academic objectives in Iranian universities which can be either autonomous or controlled. Learning SelfRegulation Questionnaire (SRQ-L) (Black \& Deci, 2000) measures the reasons why people learn in particular settings, such as university. It consists of two subscales: Controlled Regulation (extrinsic motivation) and Autonomous Regulation (intrinsic motivation). The participants were asked to rate how true each of the 12 reasons are for participating in their university courses. Responses to each of these items are made on a 7-point Likert scale ranging from not at all true (1) to very true (7). Four of these reasons were intrinsic or identified and eight were external or introjected. Alpha reliabilities were .75 for controlled regulation and .80 for autonomous regulation.

\subsubsection{Academic Identity Status questionnaire}

The Academic Identity Status Measure (Was \& Isaacson, 2008) employed in the present study has been designed to recognize the students' identity status type with regard to their academic university education. AIS measure contains four subscales, Moratorium $(\alpha=0.79)$, Foreclose $(\alpha=0.51)$, Diffuse $(\alpha=0.52)$, and Achievement $(\alpha=0.81)$, each with ten items. Results of exploratory factor analysis $(\mathrm{KMO}=0.874$, Bartlett's Test of Sphericity $=3269.278$, df $=780$, $\mathrm{Sig}=0.0001$ ) indicated the considerable and significant contribution of each of the items in measuring academic identity status.

\subsection{Data Collection Procedure}

The study was conducted during spring, autumn, and winter of 2018-2019. The data were collected using four questionnaires as explained above. The valid and reliable measures were applied in order to identify students' perceived classroom climate, their academic self-concept, learning self regulation, and academic identity status. Ethics approval was sought and the students were informed of the research objectives. They were also told that there is no obligation to participate in the study and that their responses will be kept anonymous and totally confidential.

\subsection{Data Analysis}

AMOS version 21 was applied to estimate the matrix of correlations assumed in our hypothesized model using SEM analyses. The assumptions of normal distribution and linearity should also be met for the SEM to analyze the proposed model. SEM involves two phases of exploratory factor analysis and confirmatory factor analysis. Firstly, exploratory 
factor analysis was conducted to validate the subscales or observed variables which we considered for each of our main or latent variables along with Kaiser-Meyer-Olkin Measure of Sampling Adequacy (KMO) and Bartlett's Test of Sphericity. Secondly, confirmatory factor analysis was run to investigate the validation of the full posited model using various goodness of fit indices. Multiple regression analysis was also conducted to examine the extent to which each variable predicts AIS.

Further, to evaluate the fit of the hypothetical model, the fit indices involving chi-square, root mean square error of approximation (RMSEA), root mean squared residual (RMR), goodness of fit index (GFI), normal fit index (NFI), comparative fit index (CFI), adjusted goodness of fit index (AGFI), as well as incremental fit index (IFI) were applied in the study. The values of GFI, NFI, CFI, and IFI> .90 are regarded as acceptable fitness indices. The index for AGFI is acceptable when it is greater than .85 , for RMR when it is equal or greater than 0 , for RMSEA when it is less than .05 and in case of normal chi- square when it is greater than 5 (Byrne, 2001; Hu \& Bentler, 1999).

\section{Results}

Having considered the various analyses techniques, the following results were obtained: Table 1 presents the descriptive statistics of all the subscales of the main variables.

Table 1. Descriptive statistics for all the variables in the study

\begin{tabular}{|c|c|c|c|c|c|c|c|}
\hline & $\mathrm{N}$ & Mean & Std. Deviation & Skewness & Kurtosis & Sig. & alpha \\
\hline \multicolumn{8}{|l|}{ Classroom climate } \\
\hline Personalization & 420 & 17.2875 & 2.37381 & .209 & -.551 & .000 & .62 \\
\hline Involvement & 420 & 17.7687 & 2.79772 & .207 & .159 & .000 & .70 \\
\hline Student cohesiveness & 420 & 18.9687 & 3.40094 & .069 & -.117 & .000 & .83 \\
\hline Satisfaction & 420 & 17.2625 & 4.14697 & .097 & -.498 & .000 & .79 \\
\hline Task orientation & 420 & 18.3437 & 2.22566 & -.178 & .184 & .000 & .69 \\
\hline Innovation & 420 & 16.7938 & 2.67602 & -.098 & .962 & .000 & .72 \\
\hline Individualization & 420 & 16.4938 & 2.74061 & -.169 & -.296 & .000 & .67 \\
\hline \multicolumn{8}{|l|}{ Learning Self-regulation } \\
\hline Autonomous regulation & 420 & 23.5875 & 5.31914 & -.279 & -.561 & .000 & .61 \\
\hline Controlled regulation & 420 & 30.8000 & 7.27067 & -.019 & -.050 & .000 & .59 \\
\hline \multicolumn{8}{|l|}{ Academic self-concept } \\
\hline Academic confidence & 420 & 35.0937 & 6.08384 & .124 & -.831 & .000 & .71 \\
\hline Academic effort & 420 & 33.8750 & 4.94959 & .248 & .171 & .000 & .68 \\
\hline \multicolumn{8}{|l|}{ Academic identity status } \\
\hline Foreclosure & 420 & 28.5438 & 6.35309 & 1.039 & 1.981 & .000 & .55 \\
\hline Diffusion & 420 & 26.9938 & 6.88508 & .202 & -.393 & .000 & .60 \\
\hline Achievement & 420 & 35.3500 & 5.71332 & -.207 & -.399 & .000 & .72 \\
\hline Moratorium & 420 & 30.1313 & 7.41017 & .106 & .072 & .000 & .65 \\
\hline Valid N (listwise) & 420 & & & & & & \\
\hline
\end{tabular}


As Table 1 reveals, the continuous variables have not been normally distributed (Skewness and Kurtosis $<2$ ). Thus, Spearman Bivariate Correlation was run to see the estimate and the direction of the relations. Table 2 represents the correlation matrix for all the variables and subscales in the study.

Table 2. Correlation matrix of the study variables

\begin{tabular}{|c|c|c|c|c|c|c|c|c|c|c|c|c|c|c|c|c|c|c|c|}
\hline Variables & $\mathrm{CC}$ & 1 & 2 & 3 & 4 & 5 & 6 & 7 & LSR & 8 & 9 & ASC & 10 & 11 & AIS & 12 & 13 & 14 & 15 \\
\hline $\begin{array}{l}\text { Classroom } \\
\text { climate }\end{array}$ & - & & & & & & & & & & & & & & & & & & \\
\hline 1.Personalization & $\begin{array}{l}.648 * \\
*\end{array}$ & - & & & & & & & & & & & & & & & & & \\
\hline 2.Involvement & $\begin{array}{l}.715^{*} \\
*\end{array}$ & $\begin{array}{l}.321 \\
* *\end{array}$ & - & & & & & & & & & & & & & & & & \\
\hline $\begin{array}{l}\text { 3.Student } \\
\text { cohesiveness }\end{array}$ & $\begin{array}{l}.434 * \\
*\end{array}$ & $\begin{array}{l}.195 \\
* *\end{array}$ & $\begin{array}{l}.213 \\
* *\end{array}$ & - & & & & & & & & & & & & & & & \\
\hline 4.Satisfaction & $\begin{array}{l}.839 * \\
*\end{array}$ & $\begin{array}{l}.552 \\
* *\end{array}$ & $\begin{array}{l}.571 \\
* *\end{array}$ & $\begin{array}{l}.224 \\
* *\end{array}$ & - & & & & & & & & & & & & & & \\
\hline 5.Task orientation & $\begin{array}{l}.482 * \\
*\end{array}$ & $\begin{array}{l}.191 \\
* *\end{array}$ & $\begin{array}{l}.306 \\
* *\end{array}$ & $\begin{array}{l}.148 \\
* *\end{array}$ & $\begin{array}{l}.472 \\
* *\end{array}$ & - & & & & & & & & & & & & & \\
\hline 6.Innovation & $\begin{array}{l}.479 * \\
*\end{array}$ & $\begin{array}{l}.264 \\
* *\end{array}$ & $\begin{array}{l}.279 \\
* *\end{array}$ & $\begin{array}{l}.113 \\
* *\end{array}$ & $\begin{array}{l}.221 \\
* *\end{array}$ & 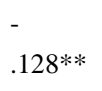 & - & & & & & & & & & & & & \\
\hline $\begin{array}{l}\text { 7.Individualizatio } \\
\mathrm{n}\end{array}$ & $\begin{array}{l}.567 * \\
*\end{array}$ & $\begin{array}{l}.240 \\
* *\end{array}$ & $\begin{array}{l}.339 \\
* *\end{array}$ & .035 & $\begin{array}{l}.409 \\
* *\end{array}$ & $.169 * *$ & $\begin{array}{l}.3 \\
80 \\
* *\end{array}$ & - & & & & & & & & & & & \\
\hline $\begin{array}{l}\text { Learning Self- } \\
\text { regulation }\end{array}$ & $\begin{array}{l}.168 * \\
*\end{array}$ & $\begin{array}{l}.112 \\
*\end{array}$ & .056 & .026 & $\begin{array}{l}.215 \\
* *\end{array}$ & $.331 * *$ & $\begin{array}{l}- \\
.0 \\
75\end{array}$ & $\begin{array}{l}.12 \\
2^{* *}\end{array}$ & - & & & & & & & & & & \\
\hline $\begin{array}{l}\text { 8.Autonomous } \\
\text { regulation }\end{array}$ & $\begin{array}{l}.312 * \\
*\end{array}$ & $\begin{array}{l}.222 \\
* *\end{array}$ & $\begin{array}{l}.103 \\
* *\end{array}$ & .028 & $\begin{array}{l}.327 \\
* *\end{array}$ & $.354 * *$ & $\begin{array}{l}- \\
.0 \\
53\end{array}$ & $\begin{array}{l}.13 \\
2^{* *}\end{array}$ & $\begin{array}{l}.825 \\
* *\end{array}$ & - & & & & & & & & & \\
\hline $\begin{array}{l}\text { 9.Controlled } \\
\text { regulation }\end{array}$ & $\begin{array}{l}.032 * \\
*\end{array}$ & .000 & -.009 & -.077 & -.060 & $.338^{* *}$ & $\begin{array}{l}- \\
.0 \\
68\end{array}$ & $\begin{array}{l}.08 \\
3\end{array}$ & $\begin{array}{l}.898 \\
* *\end{array}$ & $\begin{array}{l}.52 \\
6 * *\end{array}$ & - & & & & & & & & \\
\hline $\begin{array}{l}\text { Academic self- } \\
\text { concept }\end{array}$ & $\begin{array}{l}.211^{*} \\
*\end{array}$ & .083 & $\begin{array}{l}.239 \\
* *\end{array}$ & $\begin{array}{l}.243 \\
* *\end{array}$ & $\begin{array}{l}.354 \\
* *\end{array}$ & $.248 * *$ & $\begin{array}{l}- \\
.2 \\
24 \\
* *\end{array}$ & $\begin{array}{l}.06 \\
9 * *\end{array}$ & $\begin{array}{l}.220 \\
* *\end{array}$ & $\begin{array}{l}.29 \\
4 * *\end{array}$ & .083 & - & & & & & & & \\
\hline $\begin{array}{l}\text { 10.Academic } \\
\text { confidence }\end{array}$ & $\begin{array}{l}.148 * \\
*\end{array}$ & .066 & $\begin{array}{l}.180 \\
* *\end{array}$ & $\begin{array}{l}.227 \\
* *\end{array}$ & $\begin{array}{l}.176 \\
* *\end{array}$ & $.204 * *$ & $\begin{array}{l}- \\
.2 \\
08 \\
* *\end{array}$ & $\begin{array}{l}- \\
.11 \\
8^{*}\end{array}$ & $\begin{array}{l}.185 \\
* *\end{array}$ & $\begin{array}{l}.21 \\
6 * *\end{array}$ & .086 & $\begin{array}{l}.918 \\
* *\end{array}$ & - & & & & & & \\
\hline $\begin{array}{l}\text { 11.Academic } \\
\text { effort }\end{array}$ & $\begin{array}{l}.237 * \\
*\end{array}$ & .075 & $\begin{array}{l}.242 \\
* *\end{array}$ & $\begin{array}{l}.215 \\
* *\end{array}$ & $\begin{array}{l}.298 \\
* *\end{array}$ & $.249^{* *}$ & $\begin{array}{l}.1 \\
72 \\
* *\end{array}$ & $\begin{array}{l}.00 \\
2\end{array}$ & $\begin{array}{l}.209 \\
* *\end{array}$ & $\begin{array}{l}.31 \\
0 * *\end{array}$ & .069 & $\begin{array}{l}.827 \\
* *\end{array}$ & $\begin{array}{l}.55 \\
5 * \\
*\end{array}$ & - & & & & & \\
\hline
\end{tabular}




\begin{tabular}{|c|c|c|c|c|c|c|c|c|c|c|c|c|c|c|c|c|c|c|}
\hline Academic identity & - & - & - & - & - & - & .1 & .01 & .141 & .01 & .243 & - & - & - & - & & & \\
\hline \multirow[t]{3}{*}{ status } & $.159 *$ & .007 & .132 & .245 & .169 & $.156^{* *}$ & 10 & 9 & $* *$ & 2 & $* *$ & .275 & .25 & .20 & & & & \\
\hline & $*$ & & $*$ & $* *$ & $* *$ & & $* *$ & & & & & $* *$ & $6 *$ & $2 *$ & & & & \\
\hline & & & & & & & & & & & & & $*$ & $*$ & & & & \\
\hline \multirow[t]{4}{*}{ 12.Forclosure } & - & .072 & -.011 & - & -.036 & -.088 & .1 & .07 & .216 & .13 & .245 & - & - & - & .717 & - & & \\
\hline & $.012 *$ & & & .155 & & & 50 & 6 & $* *$ & $6^{* *}$ & $* *$ & .112 & .15 & .02 & $* *$ & & & \\
\hline & $*$ & & & $* *$ & & & $* *$ & & & & & $* *$ & $6^{*}$ & $7 *$ & & & & \\
\hline & & & & & & & & & & & & & $*$ & $*$ & & & & \\
\hline \multirow[t]{4}{*}{ 13.Diffusion } & - & - & - & - & - & - & .1 & .01 & -.042 & - & .097 & - & - & - & .778 & .43 & - & \\
\hline & $.245 *$ & .124 & .199 & .297 & .265 & $.226 * *$ & 22 & 7 & & .17 & & .502 & .44 & .41 & $* *$ & $6^{*}$ & & \\
\hline & $*$ & $*$ & $* *$ & $* *$ & $* *$ & & $*$ & & & $1 * *$ & & $* *$ & $9 *$ & $1 *$ & & $*$ & & \\
\hline & & & & & & & & & & & & & $*$ & $*$ & & & & \\
\hline \multirow[t]{4}{*}{ 14.Achievement } & $.234 *$ & .081 & .126 & .033 & .202 & $.136^{*}$ & - & .05 & .253 & .39 & .188 & .573 & .51 & .49 & .119 & .10 & - & - \\
\hline & & & $*$ & & $*$ & & .1 & 8 & $* *$ & $0 * *$ & $* *$ & $* *$ & $4^{*}$ & $0 *$ & $* *$ & $8^{*}$ & .25 & \\
\hline & & & & & & & 05 & & & & & & $*$ & $*$ & & $*$ & $2 *$ & \\
\hline & & & & & & & & & & & & & & & & & $*$ & \\
\hline \multirow[t]{4}{*}{ 15.Moratorium } & - & .097 & .209 & - & - & - & .0 & - & .073 & .06 & .197 & - & - & - & $.8 * *$ & .41 & .64 & - \\
\hline & $.269 *$ & & $* *$ & .307 & .286 & $.175^{* *}$ & 94 & .07 & & 7 & $* *$ & .415 & .37 & .33 & & $* *$ & $4 *$ & .16 \\
\hline & $*$ & & & $* *$ & $* *$ & & & 1 & & & & $* *$ & $7 *$ & $* *$ & & 8 & $*$ & $4 * *$ \\
\hline & & & & & & & & & & & & & $*$ & & & & & \\
\hline
\end{tabular}

As represented in Table 2, besides the intra-scales significant associations in each main variable, there were some significant relations among different main variables and subscales in the study. CC was positively correlated with subscales of LSR and ASC; whereas it was negatively associated with AIS. Variables of CC were correlated with ASC in which the strongest relation was with task orientation and between academic effort and task orientation in specific. ASC and its subscales were also significantly linked to autonomous regulation. ASC and its subscales were negatively correlated with AIS and its underlying subscales. The strongest negative relation was between ASC and diffusion; however, ASC had a positive strong relation with achievement leading to strong relations between the subscales of academic confidence and academic effort and the achievement identity status. Moratorium was also negatively correlated with ASC and its subscales.

Significant positive relations were also identified between autonomous self-regulation and all the variables of CC. Yet, the strongest relations were held between autonomous regulation and the main variable of CC as well as classroom climate task orientation and the main variable of LSR Personalization, task orientation and satisfaction were correlated with autonomous regulation. Autonomous regulation was also correlated with classroom climate satisfaction. Task orientation was also linked to controlled regulation. LSR was correlated with foreclosure, achievement, and moratorium positively and with diffusion negatively in which the strongest relations were made between foreclosure and controlled regulation as well as autonomous regulation and achievement.

Negative correlations were identified between diffusion and CC subscales, the strongest one between diffusion and student cohesiveness. However, there was a positive correlation between the scale of CC and the identity status of achievement. Significant correlations were found between different subscales of CC and moratorium status. However, the strongest positive relation was identified between student cohesiveness and moratorium. Although multiple relationships were found among various subscales of different variables, simple correlation analysis could not be accounted as a strong confirmatory measure to suggest accuracy of these relations in the network of associations among different components of the hypothesized model. Therefore, the significant relationships in the network of associations were probed via SEM procedure in exploratory and confirmatory phases.

At the exploratory stage of our analysis and in order to ascertain about sufficiency of sampling and appropriateness of the factor model for each of our main variables, KMO measure of sampling adequacy and Bartlett's Test of Sphericity were estimated. As shown in Table 3, all the statistics for KMO measure were greater than 0.5 implying sufficiency 
of sampling. Furthermore, confidence level of 0.00 for Bartlett's test conveyed appropriateness of factor model for all of our main variables.

Table 3. KMO and Bartlett's test of study variables

\begin{tabular}{llc}
\hline KMO and Bartlett's Test & & \\
\hline \multicolumn{2}{l}{ Kaiser-Meyer-Olkin Measure of Sampling Adequacy. } & .653 \\
\hline Bartlett's Test of Sphericity & Approx. Chi-Square & 81.650 \\
& Df & 6 \\
& Sig. & .000 \\
\hline
\end{tabular}

Following the confirmatory approach, the schematic representation of the final model with standardized path coefficients is presented in Figure 2. As shown in the figure, the values of factor loadings and residuals, and the overall model fit indices meet the assumptions of the acceptable levels (Table 4). To begin with, the ratio of the chi-square to degrees of freedom $\left(\mathrm{x}^{2} / \mathrm{df}\right)$ in the present study is 2.851 which is desirable. Moreover; all the selected model fit indices display very good levels.

Table 4. Structural equation model: fit statistics

\begin{tabular}{llll}
\hline Fit statistics & Acceptable level & current level & Evaluation \\
\hline $\begin{array}{l}\text { Normal chi-Square } \\
\text { Root Mean Squared Error of }\end{array}$ & $2<(\mathrm{x} 2 / \mathrm{df})<5$ & 2.851 & Accept \\
$\begin{array}{l}\text { Approximation } \\
\text { Root Mean Squared Residual }\end{array}$ & RMR $\geq 0$ & 0.0437 & Accept \\
Goodness-of-Fit Index & GFI $>0.9$ & 1.576 & Accept \\
Adjusted Goodness-of-Fit Index & AGFI $>0.85$ & 0.926 & Accept \\
$\begin{array}{l}\text { Normal Fit Index or Bentler-Bonett } \\
\text { Index }\end{array}$ & NFI $>0.90$ & 0.868 & Accept \\
Comparative Fit Index & CFI $>0.90$ & 0.934 & Accept \\
Incremental Fit Index & IFI $>0.90$ & 0.920 & Accept \\
\hline
\end{tabular}

As it is seen in Figure 2, links among the variables of CC, ASC, LSR, and AIS were of direct, positive, and reciprocal type. However, there were negative relations between AIS and the variables of LSR and ASC with the strongest association between AIS and ASC (-.71). The next strongest links were found between participants' perceived CC and AIS (-.3) as well as CC and ASC (.28). In addition to the relations found among the main variables of the study, various subscales of one particular variable as well as various subscales of different variables tended to be associated with each other in either positive or negative directions.

In case of CC, relations were identified with the subscales of LSR and ASC. Among the components of classroom climate, student cohesiveness was negatively correlated with satisfaction and individualization. A negative correlation was also identified between task orientation and innovation; however, innovation was correlated with individualization in a positive direction. Task orientation was linked to autonomous and controlled regulation. Involvement was also 
related to autonomous regulation. Student cohesiveness and individualization were negatively associated with academic confidence.

With regard to the subscales of AIS, academic identity achievement and foreclosure were found to be related to each other and they both correlated with academic effort. Moreover, achievement had correlations with both components of the two scales of ASC and LSR. Foreclosure was also linked to subscales of LSR. Furthermore, the subscales of AIS exhibited relations with the subscales of ASC and LSR. Moratorium and diffusion were also linked to controlled regulation. Among these relations, the link between student cohesiveness and satisfaction was the strongest (- .7). Yet, the relations between achievement and academic effort (.59) and confidence (.55) also demonstrated strong associations. The moderate relations contributed to the links between moratorium and controlled regulation (.35), foreclosure and academic effort (.34), innovation and individualization (.31), foreclosure and controlled regulation (.30), and diffusion and controlled regulation (.28).

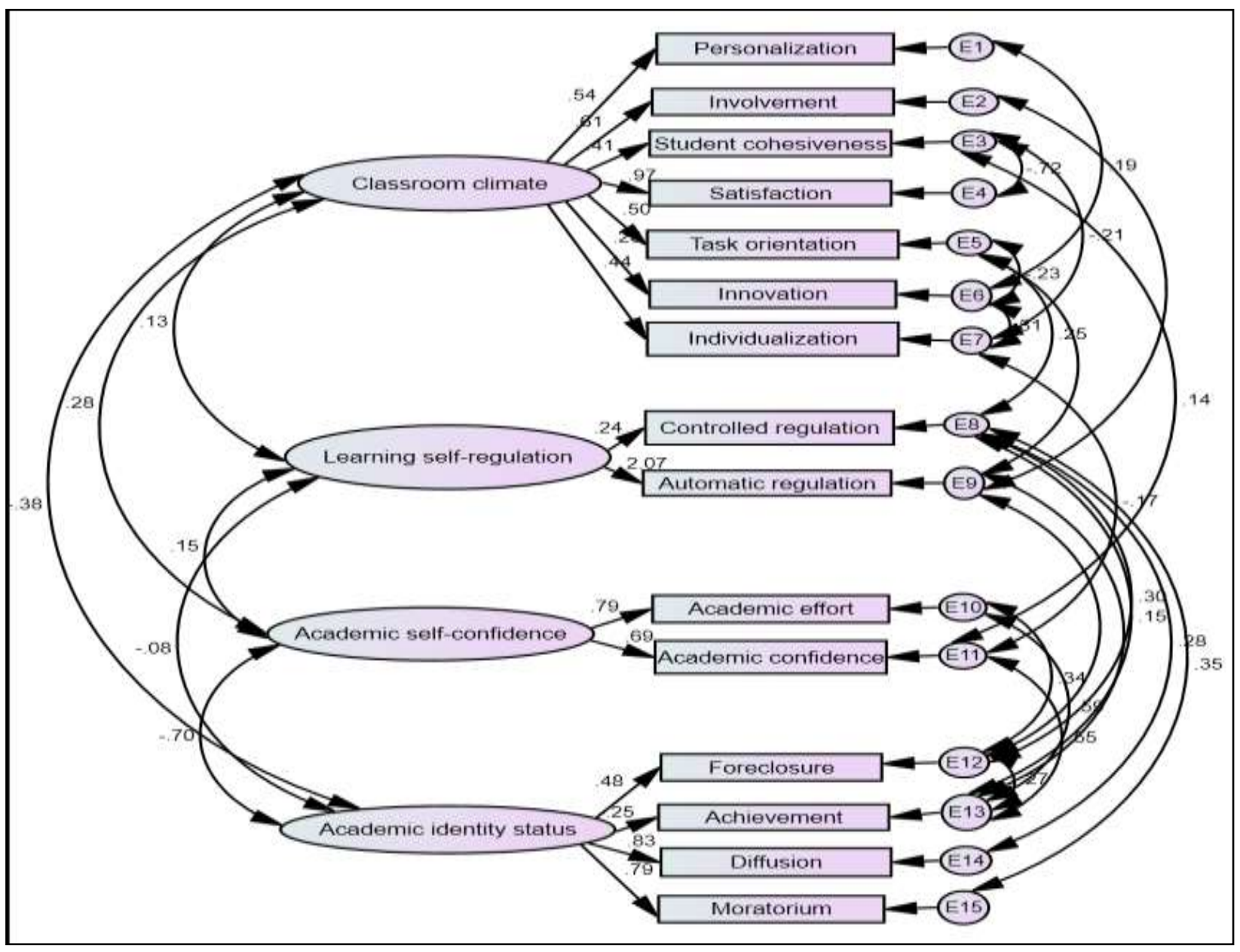

Figure 2. Structural model of relations among the study variables and subscales

To see how the main variables of study load on each other and how predictions are made, a multiple regression was also run. Table 5 represents the related findings. 
Table 5. Multiple regressions with classroom climate and learning self-regulation and academic self-concept as independent variables and academic identity status as dependent variable

\begin{tabular}{llll}
\hline Academic identity status & & $\mathrm{T}$ & Sig. \\
\hline Constant & $\mathrm{B}$ & 15.580 & .000 \\
Classroom climate & -.152 & -.2 .867 & .004 \\
Learning self-regulation & .279 & 5.277 & .000 \\
Academic self-concept & -.287 & -5.396 & .000 \\
$\mathrm{~F}=19.885$ & & $\mathrm{Sig}=.000$ & \\
$\mathrm{R}=.40$ & & $R^{2}=.16$ \\
\hline
\end{tabular}

Multiple regression analysis indicated that LSR and ASC predict AIS more powerfully than CC. As it is indicated by their $\beta$ and $t$ values, among these measures, ASC and CC were negative predictors of AIS; whereas, LSR was a negative predictor of AIS. Table 5 shows that a combined interaction between CC, LSR, and ASC predicts $16 \%$ of variance in AIS.

\section{Discussion}

Our analyses revealed an interesting network of associations among a number of Iranian EFL learners' perceived academic classroom climate and some of their academic characteristics. Taken together, these results, obtained from the correlation matrix and SEM analysis, yielded a number of valuable and practical implications for students and teachers on the interconnections between CC, ASC, LSR, AIS, as well as on their respective subscales. Some previous studies reported connections between CC and ASC (Knight \& Waxman, 1990; Sharifi Saki, Fallah, \& Zareii Mahmoodabadi, 2013; Singh \& Sarkar, 2015). Our study also identified associations between the two variables, the strongest of which concerned the links between academic effort and task orientation. This finding also aligns with Persad (1980). Based on what we have experienced in Iranian classes, this can imply that students try more when they evaluate their class events and assignments as self-evident, planned, and organized. It can also be identified that those learners with low academic confidence tend to be more cohesive and connected with their classmates and friends.

A significant relation between academic self-concept and autonomous regulation showed that Iranian learners with higher academic confidence and effort are more autonomously regulated having more intrinsic and identified reasons for their academic studies. Among the strongest and positive relations are the ties between ASC subscales and AIS. This goes with what we have seen in Iranian universities where students who have higher commitments to academic values have higher amounts of effort and confidence during their academic projects. The link between academic effort and foreclosure also implied that foreclosed learners who value the opinions of other people, including parents and friends in deciding upon their academic objectives do more academic effort to arrive at their academic goals. Moreover, it can be perceived that diffuse learners who are less interested in academic exploration and commitment hold less academic effort and confidence in their university education in Iran. Furthermore, uncertain and indecisive learners have lower degrees of academic confidence and effort.

Phinney, Dennis, and Osorio (2006) suggest that a limited amount of research has been done on the motivation to attend university and factors contributing to AIS. Yet, negative and positive correlations were found between CC and AIS subscales. The results demonstrated that achieved identity status learners perceive their classes as having higher degrees of each of the subscales of CC. A negatively strong relation between student cohesiveness and diffusion also implies that students with diffuse identity status who poorly get involved in academic exploration and commitment tend to have a low degree of cohesiveness, intimacy, and cooperation with their friends. Another strong relation between student cohesiveness and moratorium also suggested that learners who are more uncertain and cannot decide easily through exploring situations to reach academically related goals and values tend to be more cohesive with their friends and ask more for their friends' assistance. These findings reflect the significant attention that Iranian EFL 
teachers must pay to cooperative opportunities which can greatly enhance students' decisiveness and commitment to academic goals and values.

The main variable and subscales of CC and those of LSR were found to have links with each other as well. This is congruent with the findings of Liu et al. (2009), Ross et al. (2003), Ryan and Connel (1989), Paris and Paris (2001), and Sungur and Gungoren (2009). It was identified that when class activities are clear and well-organized, the students are more learning self-regulated. Moreover, classes with emphasis on opportunities for students to interact with instructors and the instructors' concern for students' personal welfare tend to result in more autonomously regulated learners. It was also noticeable that learners with autonomous regulation enjoy their classes more than other learners and participate actively and attentively in class discussions and activities. These findings are all significant in the Iranian EFL contexts where most of the learning takes place in the class. This signifies the important role of the teachers in setting the climate in a way that boosts students' autonomous learning regulation.

Allan, Johnson, and Szostak (2009) supported the effect of identity status on motivation to attend university. In the same vein, on the basis of our obtained results, foreclosed academic identity holders who grasp their academic values and goals from significant others are more extrinsically motivated, avoid punishments, and try to satisfy others. Besides, given the model, extrinsically motivated learners are more uncertain about their goals and values and tend to be less committed to them. Achieved academic identity holders committed to their academic values, on the other hand, are autonomously and intrinsically learning regulated. Besides, learners who are less committed to academic values generally have a low amount of learning controlled and autonomous regulation. Although no precise study was found to explore the links between learners' AIS and LSR, our study partly provides parallel evidence for the previous research conducted by Was et al. (2009) which showed that there is a relation between AIS and achievement goals.

Considering the subscales of each main variable, some negative and positive correlations were identified based on the derived SEM model. A negative link between task orientation and innovation shows that students who recognize their class activities and assignments as more clear, pre-planned, and orderly perceive their instructors bringing less new and unusual activities and teaching techniques to the classroom setting. This has been frequently observed in our university classes. Furthermore, students who feel more connected and friendly with their friends and much in need of their classmates' assistance perceive their classes as having less individualization and have a lower degree of enjoyment of their class activities.

However, it was found that classroom climates with higher innovation opens more room for Iranian EFL teachers' consideration of students' individual differences. With reference to AIS subscales, a strong relation between achievement and foreclosure suggests that learners with foreclosed identity status purport to achieve more if they have more commitments to their academic responsibilities and values. The regression results also reveal the more significant influence that a joint interaction between ASC and LSR can have on AIS than CC. This implies that students' amount of effort and confidence and their ability to manage cognition and leaning can considerably affect their academic identity development.

\section{Conclusion}

In this study, SEM analysis was used to provide a more precise estimate of the relationships among the four variables. The results indicated that all the main variables and some of their subscales proved to be associated with each other either in positive or negative directions. The study yields several implications. The network of links demonstrates that classroom teachers, curriculum planners, university managers and others involved in higher education must take into account the potential links between different factors in any classroom climate and more specifically in EFL academic settings. This includes the links between the classroom climate and students' various academic characteristics involving their status of regulation, self-concept and identity. Individuals bring their specific properties into the classes contributing to their degree of success or failure. However, it is of paramount significance to consider that these properties can either be influenced by or affect the diverse features of any classroom climate. The findings also enrich our understanding of the contribution of different classroom psychosocial aspects to learners' distinct capabilities. All these aspects can have great contributions to learners' different capabilities scarcely studied in EFL settings. It is suggested that, due to the unavoidable importance of the interconnections, syllabus designers, language programmers, EFL instructors, and others involved in higher education need to identify the associations among learners' perceived academic climate, their self-concept, ability to self-regulate learning, and motivations to enter universities and continue higher education and then try to transform aspects of classroom climate to ensure developed academic outcomes. 
Conducting the current research incorporated some limitations which lead to some suggestions for further research. Since this is the first study in an Iranian EFL context examining the inter-correlations among CC, ASC, LSR, AIS and their respective subscales, the results should be treated with caution. This study has only examined student variables. However, it could be conducted with respect to some teacher or student-teacher variables. Students' preferred CC can also be examined in connection with other academic and cognitive attributes. Moreover, the current study has been conducted in university settings. Thus, it can be replicated to see the results concerning the main variables in the study and their corresponding relations in places other than universities like public and private schools, or language institutes. Also, it warrants separate studies to examine other individual learner characteristics as predictors of academic identity status. This research does not examine how some mediating variables affect the results. Future research thus can be conducted to analyze the possible contribution of gender, age, first language, level of education, and cultural background of both learners and teachers to the identified relations. The variables can also be studied in relation to other academically related elements as well as learners' actual academic attainment data.

\section{References}

Alzubaidi, E., Aldridge, J. M., Khine, M. S. (2016). Learning English as a second language at the university level in Jordan: Motivation, self-regulation and learning environment perceptions. Learning Environments Research, 19(1), 133-152. https://doi.org/10.1007/s10984-014-9169-7

Aldridge, J. M., \& Fraser, B. J. (2008). Outcomes-focused learning environments: determinants and effects. Sense Publishers. Rotterdam, the Netherlands.

Allan, L. J., Johnson, J. A., \& Szostak, C. (2009). Understanding the relationship between identity status, identity style, academic self-efficacy and first year students' motivation to attend university. Paper presented in part as a poster at the American Psychological Association meeting. August 6 - 9, Toronto, Canada.

Anderson, A. (2001). The effect of locus of control and classroom climate on motivation in the classroom: An ecological approach to personality and action. Ph.D. thesis, University of Auckland.

Areepattamannil, S. (2011). Academic self-concept, academic motivation, academic engagement, and academic achievement: a mixed methods study of Indian adolescents in Canada and India. A Ph.D. dissertation. Queen's University. Canada.

Awan, R. N., Noureen, G., \& Naz, A. (2011). A study of relationship between achievement motivation, self-concept and achievement in English and Mathematics at secondary level. International Education Studies, 4(3), 72-79. doi: $10.5539 /$ ies.v4n3p72

Black, A. E., \& Deci, E. L. (2000). The effects of instructors' autonomy support and students' autonomous motivation on learning organic chemistry: A self-determination theory perspective. Science Education, 84, 740-756. https://doi.org/10.1002/1098-237X(200011)84:6<740::AID-SCE4>3.0.CO;2-3

Bong, M., \& Clark, R. E. (1999). Comparison between self-concept and self-efficacy in academic motivation research. Educational Psychologist, 34(3), 139-153. doi: 10.1207/s15326985ep3403_1

Buch, J. (2007). Identity negotiation and construction: a case study of two Costa Rican women learning English. MA thesis. University of Hamline.

Byrne, B. M. (2001). Structural equation modeling with AMOS. Basic concepts, applications, and programming. Mahwah, N.J.: Lawrence Erlbaum Ass.

Dabbagh, N., \& Kitsantas. A. (2012). Personal learning environments, social media, and self-regulated learning: A natural formula for connecting formal and informal learning. The Internet and Higher Education, 15(1), 3-8. doi: 10.1016/j.iheduc.2011.06.002

Deci, E. L., \& Ryan, R. M. (2000). The “what" and "why”' of goal pursuits: Human needs and the self-determination of behavior. Psychological Inquiry, 11(4), 227-268. doi: 10.1207/S15327965PLI1104_01

DeMarie, D., Miller, P. H., Ferron, J., \& Cunningham, W. R. (2004). Path analysis tests of theoretical models of children's memory performance. Journal of Cognition and Development, 5(4), 461-492. https://doi.org/10.1207/s15327647jcd0504_4 
Dorman, J. P. (2001) Associations between classroom environment and academic efficacy. Learning Environments Research, 4, 243-257. https://doi.org/10.1023/A:1014490922622

Dorman, J. P., Fisher, D. L., \& Waldrip, B. G. (2006). Learning environments, attitudes, efficacy and perceptions of assessment: A LISREL analysis. In D. L. Fisher \& M. S. Khine (Eds.), Contemporary approaches to research on learning environments (pp. 1-28). Singapore: World Scientific.

Ebrahimi, N. A., Eskandari, Z., \& Rahimi, A. (2013). The effects of using technology and the internet on some Iranian EFL students' perceptions of their communication classroom environment. Teaching English with Technology, 13(1), 3-19. https://files.eric.ed.gov/fulltext/EJ1144160.pdf

Erten, I. H., \& Burden, R. L. (2014). The relationship between academic self-concept, attributions, and L2 achievement. System, 42(1), 391- 401. doi: 10.1016/j.system.2014.01.006

Fraser, B. J. (1998). Classroom environment instruments: Development, validity and applications. Learning Environments Research, 1, 7-34. https://doi.org/10.1023/A:1009932514731

Fraser, B. J., \& Treagust, D. F. (1986). Validity and use of an instrument for assessing classroom psychosocial environment in higher education. Higher Education, 15, 37-57. https://doi.org/10.1007/BF00138091

Frenzel, A. C., Pekrun, R., \& Goetz, T. (2007). Perceived learning environment and students' emotional experiences: A multilevel analysis of mathematics classrooms. Learning and Instruction, 17(5), 478-493. https://doi.org/10.1016/j.learninstruc.2007.09.001

Herring, A. H. (2013). Examination of motivational factors in high school dropouts participating in general education development degree programs. Journal of Organizational Learning and Leadership, 11(2), 60-68.

Hu, L., \& Bentler, P. M. (1999). Cut-off criteria for fit indices in covariance structure analysis: Conventional criteria versus new alternatives. Structural Equation Modeling: A Multidisciplinary Journal, 6(1), 1-55. https://doi.org/10.1080/10705519909540118

Jaiswal, S. K., \& Choudhuri, R. (2017). Academic self-concept and academic achievement of secondary school students. American Journal of Educational Research, 5(10), 1108-1113. doi: 10.12691/education-5-10-13

Joe, H. K., Hiver, P., \& Al-Hoorie, A. H. (2017). Classroom social climate, self-determined motivation, willingness to communicate, and achievement: A study of structural relationships in instructed second language settings. Learning and Individual Differences, $133-144$. doi: 10.1016/j.lindif.2016.11.005

Knight, S. K., \& Waxman, H. C. (1990). Investigating the effects of the classroom learning environment on student motivation in social studies. Journal of Social Studies Research, 14(1), 1-12. https://eric.ed.gov/?id=EJ431913

Lampert, J. N. (2007). The relationship of self-efficacy and self-concept to academic performance in a college sample: testing competing models and measures. MA thesis. Pacific University.

Levesque, C. S., Williams, G. C., Elliot, D., Pickering, Bodenhamer, B., \& Finley, P. J. (2006). Validating the theoretical structure of the Treatment Self-Regulation Questionnaire (TSRQ) across three different health behaviors. Health Education Research, 22(5), 691-702. doi: 10.1093/her/cyl148

Liu, H. J. (2010). The relation of academic self-concept to motivation among University EFL students. Feng Chia $\begin{array}{llllll}\text { Journal of Humanities } & \text { Social } & \text { Sciences, } & 225 .\end{array}$ http://www.fcu.edu.tw/wSite/public/Attachment/f1283494063178.pdf

Liu, W. C., Wang. C. K. J., Tan, O. S., Ee, J., \& Koh, C. (2009). A self-determination approach to understanding students' motivation in project work. Learning and Individual Differences, 19(2009), 139-145. doi: 10.1016/j.lindif.2008.07.002

Matovu, M. (2012). Academic self-concept and academic achievement among University students. International $\begin{array}{lllll}\text { Online Journal of } & \text { Educational } & \text { Sciences, } & 4(1), & 116 .\end{array}$ http://www.acarindex.com/dosyalar/makale/acarindex-1423904334.pdf 
Mohammadi, S., \& Aliakbari, M. (2018). Students' perceived classroom climate and their achievement goal orientations in an Iranian EFL context. International Journal of Foreign Language Teaching \& Research, 6 (23), 129-145. http://jfl.iaun.ac.ir/article_607356_257f9de1618d543b15780d9a314a18ef.pdf

Paris, S. C., \& Paris, A. H. (2001). Classroom applications of research on self-regulated learning. Educational Psychologist, 36(2), 89-101. https://doi.org/10.1207/S15326985EP3602_4

Pawlowska, D. K., Westerman, W., Bergman, S. M., \& Huelsman, T. J. (2014). Student personality, classroom environment, and student outcomes: A person-environment fit analysis. Learning and Individual Differences, 36, 180-193. doi: $\underline{10.1016 / \mathrm{j} . \text { lindif.2014.10.005 }}$

Peirce, B. N. (1995). Social identity, investment, and language learning. TESOL Quarterly, 29(1), 9-31. https://doi.org/10.2307/3587803 doi: 10.2307/3587803

Peng, J. E. (2019). The roles of multimodal pedagogic effects and classroom environment in willingness to communicate in English. System, 82, 161-173. https://doi.org/10.1016/j.system.2019.04.006

Peters, M. L. (2013). Examining the relationships among classroom climate, self-efficacy, and achievement in undergraduate mathematics: A multi-level analysis. International Journal of Science and Mathematics Education, 11, 459-480. https://doi.org/10.1007/s10763-012-9347-y

Persad, S. (1980). Relationship of classroom environment, teacher and student satisfaction and student self-concept. MA thesis. Wilfrid Laurier University.

Phinney, J., Dennis, J. M., \& Osorio, N. T. (2006). Reasons to attend college among ethnically diverse college students. Cultural Diversity and Ethnic Minority Psychology, 12(2), 347-366. doi: 10.1037/10999809.12.2.347

Puspoky, B. (2018). Identity status, achievement goal orientation, and academic engagement. Undergraduate Honors Theses. 76. https://ir.lib.uwo.ca/psychK uht/76

Rosen, J. A., Glennie, E. J., Dalton B. W., Lennon, J. M., \& Bozick, R. N. (2010). Noncognitive skills in the classroom: New perspectives on educational research. RTI Press publication No. BK-0004-1009. Research Triangle Park, NC: RTI International. https://www.rti.org/sites/default/files/resources/bk-0004-1009-rosen.pdf

Ross, M. E., Salisbury-Glennon, J. D., Guarino, A., Reed, C. J., \& Marshall, M. (2003). Situated self-regulation: modelling the interrelationships among instruction, assessment, learning strategies and academic performance. Educational Research and Evaluation, 9(2), 189-209. https://doi.org/10.1076/edre.9.2.189.14211

Ryan, R. M., \& Connell, J. P. (1989). Perceived locus of causality and internalization: Examining reasons for acting in two domains. Journal of Personality and Social Psychology, 57, 749-761. https://selfdeterminationtheory.org/SDT/documents/1989 RyanConnell.pdf

Sharifi Saki, S., Fallah, M. H., \& Zareei Mahmoodabadi, H. (2013). Perceived classroom environment and mathematics achievement: mathematics self- efficacy and self- concept as mediators. Journal of Applied $\begin{array}{lllll}\text { Environmental and } & \text { Biological } & \text { Sciences, } & 3(8), & \text { 69-74. }\end{array}$ https://www.textroad.com/pdf/JAEBS/J.\%20Appl.\%20Environ.\%20Biol.\%20Sci.,\%203(8)6974,\%202013.pdf

Singh, R., \& Sarkar, S. (2015). Learning environments in Andhra Pradesh, India: children's 'academic self-concept' and mathematics achievement. Working paper. Young Lives. University of Oxford.

Sun, H., \& Chen, A. (2010). An examination of sixth graders' self-determined motivation and learning in Physical Education. Journal of Teaching in Physical Education, 29, 262-277. https://libres.uncg.edu/ir/uncg/f/A_Chen_Examination_2010.pdf

Sungur, S., Güngören, S. (2009). The role of classroom environment perceptions in self-regulated learning and science $\begin{array}{lllll}\text { achievement. } & \text { Elementary } & \text { Education } & \text { Online, } & 8(3),\end{array}$ file:///C:/Users/ASUS/AppData/Local/Temp/1954-1822-1-PB.pdf

Thanasoulas, D. (2002). Motivation and motivating in the foreign language classroom, The Internet TESOL Journal, 8(11), 6-25. http://www.englishclub.com/tefl articles/motivation-motivating-efl.htm 
Wang, C. K. J., Liu, W. C. H., \& Chye, S. (2010). Achievement goals, implicit theories and behavioral regulation among polytechnic engineering students. The International Journal of Research and Review, 5(2), 1-17. http://citeseerx.ist.psu.edu/viewdoc/download?doi=10.1.1.471.3681\&rep=rep1\&type=pdf

Was, C. A., Harthy, I. A., Oden, M. S., \& Isaacson, R. M. (2009). Academic identity status and relationship to achievement goal orientation. Electronic Journal of Research in Educational Psychology, 7(2), 627-652. https://eric.ed.gov/?id=EJ869197

Was, C. A., \& Isaacson, R. M. (2008). The development of a measure of academic identity status. Journal of Research in Education, 18 (2008), 94-105.

Was, C. A., Wessel, A., \& Isaacson, R. M. (2007). Academic identity status accounts for unique variance in college students' study strategies. Association for Psychological Science 19th Annual Convention, 1-8.

Wijnia, L., Loyens, S. M. M., \& Derous, E. (2011). Investigating effects of problem-based versus lecture-based learning environments on student motivation. Contemporary Educational Psychology, 36(2), 101-113. doi: $\underline{10.1016 / j . c e d p s y c h .2010 .11 .003}$ 